\title{
Special Issues as Criterion for Journal Quality Evaluation - Letter to Editor
}

\author{
Mehdi Dadkhah', Mohammad Davarpanah Jazi ${ }^{\mathrm{A}}$ \\ Received: April 30, 2015 | Revised: May 21, 2015 | Accepted: June 10, 2015
}

Predatory publishers are defined as publishers who have financial goals. This definition was introduced for the first time by Jeffrey Beall (2012). In some predatory publishers, we can find some papers that are not related to journal's aim and scope. These journals create special issues in order to publish papers that are not related to journal's aim and scope. Thus, we are faced with a question of how the editor of these journals could evaluate these papers. In some trusted journals, editor invites guest editors for special issues, which are related to journal's aim and scope. On the other hand predatory publishers, publish papers without any external reviewers or guest editors. In addition, some journals that publish irrelevant papers in regular issues are also found. This problem can be seen especially in some biological or life science journals. It seems that these problems pose new challenge for the academic world.

Tricksters or people, who have the business view to academic world, are the main reason of this challenge. Another question that could be disscused is indexing the papers of these journals in scientific databases. For example, Journal of advanced in environmental biology is Scopus indexed for agricultural, biological and environmental science but this journal publishes papers from different domains such as computer science and management science, those papers are found in Scopus database. It means that low quality papers published in predatory journals still could be indexed in scientific databases. Therefore special issue of journals should not be accepted. Special issue is an issue focusing on certain subject and new findings about it. We believe that special issues in journals must be as a criterion to evaluate journals. With this criterion, we could detect high quality journals versus low quality ones. Table1 shows some journals with questionable special issues in 2014. These journals published regular issues behind special issues.

Table 2 shows key differences between questionable special issues and trusted ones. Authors should focus on these criteria when they decide in which journal to submit their manuscript.

We can find these questionable special issues in fake conferences that are launched by forgers. Authors are advised to use guidelines provided by Dadkhah, et al., 2015a in order to identify these conferences. It is necessary, that authors are informed about hijacked journals (Jalalian, Mahboobi, 2014; Jalalian,

Table 1. Journals with questionable special issues in 2014

\begin{tabular}{|c|l|c|c|}
\hline Journal Name* & Journal Domain & No of Special issues & No of papers in all Special issues \\
\hline Case 1 & Biological science & 10 & 133 \\
\hline Case 2 & Fisher \& Biological science & 9 & 176 \\
\hline Case 3 & Life Sciences & 1 & 350 \\
\hline Case 4 & Natural and Social Sciences & 2 & 124 \\
\hline Case 5 & Biological science & 10 & 305 \\
\hline
\end{tabular}

* The full documentation of the experiment is in possession of the authors. The paper does not provide the names of the journals, as it was only to introduce the problem and the dangers it may bring, and not to analyze the publication policies of individual journals.

A Department of Computer and Information Technology, Foulad Institute of Technology, Foulad shahr, Isfahan 8491663763, Iran Correspondence E-mail: dadkhah80@gmail.com;m.dadkhah@iautiran.ac.ir 
Table 2. Key different between questionable special issue and trusted one

\begin{tabular}{|l|l|l|l|l|}
\hline Type of Special Issue & Subject & Editor & No of Papers & $\begin{array}{l}\text { No of Special Issues } \\
\text { in year }\end{array}$ \\
\hline Trusted Special Issues & Certain subject & Guest Editor & $20-30$ & $1-2$ \\
\hline $\begin{array}{l}\text { Questionable Special } \\
\text { Issues }\end{array}$ & Multidisciplinary & Editor in Chief & $\begin{array}{l}\text { In some case over of } 50 \\
\text { papers }\end{array}$ & More than 3 \\
\hline
\end{tabular}

2014; Dadkhah, et al., 2015b), Social engineering (Dadkhah, Quliyeva, 2014), fake conferences and the above mentioned challenge in the academic world otherwise, they may become victims of hijacked journals or predatory publishers (Lukić, et al., 2014).

\section{References}

Beall, J. 2012. Predatory publishers are corrupting open access. Nature 489-7415, 179. DOI: 10.1038/489179a

Dadkhah, M., Jazi, M. D., Pacukaj, S. 2015. Fake Conferences for Earning Real Money. Mediterranean Journal of Social Sciences 6-2, 11-12. DOI:10.5901/ mjss.2015.v6n2p11

Dadkhah, M., Obeidat, M. M., Jazi, M. D., Sutikno, T., Riyadi, M. A. 2015. How Can We Identify Hijacked Journals?. Bulletin of Electrical Engineering and Informatics 4-2, 83-87. DOI: 10.12928/eei.v4i2.449.
Dadkhah, M., Quliyeva, A. 2014, Social Engineering in Academic World. Journal of Contemporary Applied Mathematics 4-2, 3-5.

Jalalian, M. 2014. Hijacked Journals Are Attacking the Reliability and Validity of Medical Research. Electronic Physician, Vol. 6, No. 4, 925-926. DOI: 10.14661/2014.925-926

Jalalian, M., Mahboobi, H. R. 2014. Hijacked Journals and Predatory Publishers: Is There a Need to ReThink How to Assess the Quality of Academic Research?, Walailak J Sci \& Tech 11-5, 389-394.

Lukić, T., Blešić, I., Basarin, B., Ivanović Bibić., Lj., Milošević, D., Sakulski, D. 2014. Predatory and Fake Scientific Journals/Publishers - A Global Outbreak with Rising Trend: A Review. Geographica Pannonica 18-3, 69-81. 